\title{
Self-extension and Purchase Behavior of Dog Related Products and Services: An In-depth Interview among Selected Malaysian Dog Owners
}

\author{
Andrew Lee Hock Cheong ${ }^{1,2} \&$ Kok Hou $\mathrm{Yi}^{1}$ \\ ${ }^{1}$ Taylor's Business School, Taylor's University, Kuala Lumpur, Malaysia \\ ${ }^{2}$ Heriot-Watt University Malaysia, Putrajaya, Malaysia \\ Correspondence: Andrew Lee Hock Cheong, Heriot-Watt University Malaysia Sdn Bhd, No.1, Jalan Venna P5/2, \\ Precinct 5, 62200 Putrajaya, Malaysia. Tel: 60-38-894-3678. E-mail: Andrew.Lee@hw.ac.uk
}

Received: January 21, 2014 Accepted: March 4, 2014 Online Published: December 30, 2014

doi:10.5539/ass.v11n3p26

URL: http://dx.doi.org/10.5539/ass.v11n3p26

\begin{abstract}
This paper discusses the findings of an explorative study among selected Malaysian dog owners who regard their dogs as extended-self and their purchase behavior of dog related products and services. A qualitative research was conducted to gain some deeper insights on purchase behavior of dog related products and services, an under research area. The study aimed to determine whether these dog owners consider their dogs as an extension of their selves and describe their purchase behavior. In-depth interviews were conducted and four major themes on purchase behavior of dog related products and services emerged, namely loving my pet dog means loving myself, sense of possession, attachment and sacrifice and my pet is like me. The findings show that generally these dog owners consider their dogs as an extension of themselves with some participants demonstrating a stronger self-extension on their pets. Dog owners who view their dogs as their extended self, made purchase decisions as though they were purchasing and consuming these products and services for themselves. This understanding offers practical insight to marketers when marketing dog related products and services.
\end{abstract}

Keywords: self-extension, in-depth interviews, dog products and services

\section{Introduction}

Pets are becoming an important part of our lives. Dogs, cats, birds, fishes, rabbits and even snakes and other exotic animals have become common pets in many households. They are cared for various reasons from being cute, adorable and also to reflect on one's personality. Some owners of these pets are willing to part with large sums of monies to own and care for their pets.

In this study, pet dogs are chosen as they are becoming increasingly popular among Malaysians. Euromonitor (2013) reported that $9 \%$ of the total pet population of 3.8 million in Malaysia in 2012 comprises of dogs. Pet dogs not only keep us company but also provide unconditional love. They act as the eyes and limbs for the disabled and play an effective role to deter intruders in homes. Given their intelligence, strong sense of loyalty or simply their cuteness, owners goes to great length in ensuring the well-being of their furry pets. From the moment a dog comes into an owner's life till its passing, it is well taken care of. Dog owners spend thousands of Ringgit in terms of acquisition of a particular dog breed, their food, clothing, grooming, obedience lessons, boarding services, healthcare, accessories and lately even bereavement services. In 2010, Malaysia was Southeast Asia's second largest pet care market with value sales of US\$105 million and an expected compounded annual growth rate of 3.2\% from 2010-2015 (Euromonitor, 2011).To a certain extent these dog owners humanize their pets and treat them as part of themselves. According to Belk (1988), pet dogs are considered as an extension of ourselves.

Hence, it is imperative that marketers understand the purchase behavior of these dog owners, specifically owners who consider their dogs as an extension of themselves. Consequently, marketers would be able to develop strategies to enhance consumption of dog related products and services.

The explorative study discussed in this paper aims to contribute to the growing literature on the purchase behavior of pet products and services and expand the limited studies pertaining to Malaysian dog owners' 
purchase behavior. Furthermore, Jyrinki and Leipamaa-Leskinen (2006) also suggested that a qualitative study is required to better understand the consumption behavior of pet owners who regard their pets as extended-self. The review of current literature revealed that existing studies specifically in the Malaysian context have scantily address Malaysian dog owners' purchase behavior.

\section{Self-extension Construct}

The self-extension construct was studied in great depth by Belk (1988) in his seminal work. Belk (1988) elaborated that "knowingly or unknowingly, intentionally or unintentionally, we regard our possessions as parts of ourselves". The possessions, argued Kiesler and Kiesler (2004), have symbolic meaning associated with a person's self-identity and definition of self. According to Jyrinki and Leipamaa-Leskinen (2006), this construct include consumers' personal and social aspects, symbolic and functional aspects and control and attachment aspects. Belk (2013) explained that areas of consumption that can be impacted by the concept of extended-self include our possession of pets. Belk (1988) cited the works of Secord (1968) who posited that pet owners develop the attitude "love me, love my dog" when pets are part of the owner's self.

The personal and social aspects in the self-extension construct were observed when Belk (1996) discovered that pet owners indicated that their pets fit into their personalities, lifestyles and families. He further added that pets can mirror both positive and negative personalities and traits of its owners.

Belk (1996) explained that symbolically pets are expressions of consumers' identities and functionally they are consumers' appendages. Jyrinki and Leipamaa-Leskinen (2006) added that objects extend consumers by assisting them to become something they desire and giving possibilities to do things they couldn't otherwise do. The type of dog breed for instance indicates dog owners' wishes to be identified with a breed. A Rottweiler for example exudes the symbol of strength and helps support consumers' who want to be identified as being masculine. On the other hand, aggressive and humorous names communicate pet owners individual or class values (Jyrinki \& Leipamaa-Leskinen, 2006). From a functional perspective, pets like dogs can be used to protect one's property, guide the handicapped and assist in rescue and security missions. In many Asian countries, pet birds for example help its owners in winning prize money in bird singing competitions.

Belk (1988) suggested that control over and by objects resulted in feeling that relates objects to consumers' identity. He further added that control over pets can be seen when pets are dressed-up and groomed, sent for obedience lessons and neutered. Pet owners' lives are also controlled by pets as pets need daily care and attention. Belk (1989) espoused that in order for an object to be extended self, consumers' should have an emotional attachment towards it. Jyrinki and Leipamaa-Leskinen (2006) explained that being closely attached to one's pet indicates that the pet is seen as part of self.

\section{Literature Review}

Subsequent to Belk's (1996) study on the self-extension construct and pet owners' relationship with their pets, Jyrinki (2005) conducted a focus group study among five Finnish dog owners from different subcultures. The subcultures included a city dog owner, a working dog owner, two home dog owners and a hunting dog owner. It was found that these owners consider their dogs as definitions of themselves. The research also discovered in different subcultures dogs were seen more as self-extension than in others. The working dog owner most often saw his dog as extended self. For the hunting dog owner, his dog is considered less as extended self. Social and visible aspects of extended self were emphasized more by the city dog owner. Nearly all aspects of the extended-self construct were observed among the two home dog owners.

Jyrinki and Leipamaa-Leskinen's (2006) continued the study on this construct in a quantitative study among 264 Finnish pet owners. They discovered that 74 of the respondents saw strongly their pets as extended self. This extended-self group emphasized more on quality, price, pleasure giving and have better self-esteem and knowledge regarding pet food consumption than the respondents who don't consider their pets as self-extension. The authors added that these pet owners are attached and wants to control their pets by giving the best quality food and take charge of their pets feeding. As these pet owners' are emotionally attached to their pets it does matter whether the pet enjoys its meal. When the pet enjoys its meal it could also refer to personal pleasure when pets are viewed as extended self. Given that the construct of extended-self incorporates personal and social aspects, being praised on their pets feeding improves the owners' self-esteem. It was also discovered in this study that owners who view pets as their extended-self planned their pets feeding more carefully and this could be related to both attachment and personal aspects of the extended-self construct. Their explorative study did not uncover any functional aspect among these respondents which they claim could be partly due to the formulation of items in their questionnaire. 
The study on consumption behavior of dog owners were further extended by Hill, Gaines and Wilson (2007) when they investigated the entire lifecycles of pet dogs among three dog owners through a qualitative study which relied on the extended-self and sacred consumption paradigms. By chronicling their lived experiences with their dogs through in-depth essays, this research developed an understanding of the consumptive life history of each dog. A total of five inter-related thematic categories which include initial engagement and selection decision; early adjustment and relationship development; permanent bond and loving intimacy; special events and life transitions and parting as such sweet sorrow were formed. These captured a variety of consumer behavior activities of these dog owners.

Our understanding on the relationship between dog owners and their dogs were further deepened through Boya, Dotson and Hyatt's (2012) cluster analysis study using shopping related variables. Through 75 in-depth interviews and the subsequent survey on 745 American dog owners they discovered three distinct segments of dog owners namely strongly attached owners, moderately attached owners and basic owners. The strongly attached owners had tendency to treat their dogs as children and themselves as their pet parents, like to spoil their dogs and celebrate their dog's birthday. Dogs are viewed as their best friend. These owners also opined that if the dogs were human, it would be like the owners. The researchers concluded that how dog owners shop for their dogs is systematically related to the nature of their relationship with their dogs. Strongly attached owners do not mind spending lots of money on purchasing gifts and healthy food for their dogs and regularly visits veterinarians. Their choice of vehicle and home set-up are also affected by their dogs.

In the Asian context, the quantitative study by Chen, Hung and Peng (2012) on pet related services identified three segments among the 578 Taiwanese pet owners' namely anthropomorphic owners who value superior quality, attached owners who seek a service's epistemic value and owners who look for interaction and a service's functional value. The first segment, though the smallest among the three, has the highest financial ability and view their pets as family members. The next segment consist of average income earners who will choose retail options that are economical, offers variety and convenience. The final and the largest group have the lowest educational and income level. They are less concern for retail shop characteristics and pet related information sources as compared with owners from the other two segments. However, this group has a strong potential for pet related service providers.

\section{Research Objective}

This exploratory study was conducted among a small selected cross section of Malaysian dog owners. This study investigated how these dog owners, who view their dogs as their extended-self, purchase pet products and services. As literature on consumption behavior of dog related products and services in Malaysia is scarce, this study will assist marketers and brand managers when marketing these product and services in Malaysia.

Hence, the objectives of the study were to (i) determine whether these dog owners consider their dogs as an extension of their selves and (ii) describe the purchase behavior among these Malaysian dog owners.

\section{Methodology}

The self-extension construct and its influence on dog owners purchasing behavior of dog related products and services provide a conceptual framework for the study. In-depth interviews with six purposively selected individuals living in Kuala Lumpur, Malaysia constitute the primary data for this research. The participants were first interviewed for a total of 1 to 1.5 hours each. Follow up interviews were conducted till saturation was achieved. These individuals were recruited through the author's personal network and a student researcher's personal contacts. The participants were selected from those who own dogs for more than 2 years as the author opines that this will yield more insights on their purchase behavior. They are from a variety of occupations and none have any theoretical background knowledge of the self-extension phenomenon being studied. In order to ensure anonymity, the participants are identified by pseudonyms throughout this paper. A brief background of the participants is shown in Table 1 .

The participants were selected based on the following criteria:

a) They own dogs as pets for over 2 years

b) They hold access to their own reasons to purchase dog products and services

c) They were willing to be interviewed and share their lived experiences with their pet dogs.

The sample size can be considered as appropriate to an explorative study using qualitative data collection techniques (Fournier, 1998; Thompson and Haytko, 1997). In addition, this sample size ensured in-depth data concerning life worlds necessary for thick description as espoused by Erlandson et al. (1993) and Mick and Buhl 
(1992) in Fournier (1998). The participants were females with only one male respondent. Previous research by Sherrod (1989) as cited by Fournier (1998) showed that females exhibited more and stronger interpersonal relationships.

Table 1. Participants' background

\begin{tabular}{|c|c|c|c|c|c|}
\hline $\begin{array}{l}\text { Participant } \\
\text { Pseudonym }\end{array}$ & Profession & Pet name(s) & $\begin{array}{l}\text { Pet's } \\
\text { gender }\end{array}$ & $\begin{array}{c}\text { Breed type(s) \& } \\
\text { Age }\end{array}$ & Products and services used \\
\hline May & Undergraduate & DeeDee & Female & Poodle, 5 & $\begin{array}{c}\text { Clothes, Dog food, } \\
\text { Grooming, Leash, } \\
\text { Treats, Veterinary } \\
\text { Supplement, Sleeping } \\
\text { basket }\end{array}$ \\
\hline Anne & Tax intern & $\begin{array}{l}\text { Casper } \\
\text { Dusty }\end{array}$ & $\begin{array}{l}\text { Male } \\
\text { Male }\end{array}$ & $\begin{array}{l}\text { Schnauzer, } 9 \\
\text { Schnauzer,4 }\end{array}$ & $\begin{array}{l}\text { Obedience lessons, } \\
\text { Dog food, Collar, } \\
\text { Grooming, Leash, } \\
\text { Treats, Veterinary, } \\
\text { Shampoo, Clothes, } \\
\text { Pet hotel, Body mist }\end{array}$ \\
\hline Pam & $\begin{array}{l}\text { University } \\
\text { lecturer }\end{array}$ & Ruby & Female & Labrador, 7 & $\begin{array}{c}\text { Dog food, Collar, } \\
\text { Grooming, Leash, } \\
\text { Cage, Veterinary, Shampoo, }\end{array}$ \\
\hline Ken & Student & Leo & Male & $\begin{array}{c}\text { Golden } \\
\text { Retriever,2 }\end{array}$ & $\begin{array}{c}\text { Dog food, Collar, } \\
\text { Grooming, Leash, } \\
\text { Treats, Veterinary, } \\
\text { Cage, Pet hotel, Pillow, } \\
\text { Obedience lessons }\end{array}$ \\
\hline Hanna & Teacher & $\begin{array}{l}\text { Happy Sam } \\
\text { Soon } \\
\text { Snaeha } \\
\text { Kimchi }\end{array}$ & $\begin{array}{c}\text { Male } \\
\text { Female }\end{array}$ & $\begin{array}{l}\text { Shih Tzu,6 } \\
\text { Chihuahua,2 }\end{array}$ & $\begin{array}{l}\text { Collar, Dog Food, } \\
\text { Grooming, Leash, } \\
\text { Treats, Veterinary, } \\
\text { Toys, Accessories }\end{array}$ \\
\hline Jen & Banker & Pico & Male & Promeranian,2 & $\begin{array}{c}\text { Dog Food, Shampoo, } \\
\text { Accessories, Harness, } \\
\text { Medication } \\
\end{array}$ \\
\hline
\end{tabular}

The interviews consisted of unstructured and open-ended questions to gain first-person description of the participant's specific experience with the purchase of dog products and services. The interview protocol questions were adopted and modified based on current literature on pet products and service consumption. In order to determine whether the participants view their pets as extended self, they were asked about their relationship with their pet dogs. This is similar to Jyrinki and Leipamaa-Leskinen (2006) approach.

All interviews were conducted either at the participants' homes or at the university where the student researcher is studying. The interviews were audio recorded with their prior consent. The interview protocol included questions about participants' backgrounds and the type of dog products and services they purchase. Probing was extensively used to elicit a rich understanding on the participants' self-extension towards their pet dogs. The interviews were conducted solely by the student researcher who had attended training on conducting in-depth interviews. The student researcher was also guided by the author. In line with Fournier (1998), the interview was designed to obtain first person descriptions of the participant's lived experiences with their dogs and contextual details concerning the participant's life world. Stories describing how they obtained and cared the dogs and their relationship with these pets were elicited. The student researcher did not impose any constraints on the elicitation. Dog products and services purchased were identified by the participants and included dog food, collar, toys, leash, supplements, accessories, obedient classes, veterinary services, pet hotel and grooming services. To stimulate and encourage discussion, the participants were with their dogs or had pictures of their dogs during the interview. The dogs involved in this study are from various breeds as shown in Table 1. 
Member checks were conducted to ensure credibility of the authors' interpretation and understanding against the participants' views. The interview texts were sent to the participants for their feedback and comments. Thereafter, the author together with the student researcher reviewed the interview transcripts. In addition to the rich description offered below, the purposive sampling of participants each with their unique experiences and understanding of the phenomena allows for transferability judgments of the insights obtained. These are in accordance with Fournier's (1998) recommendations on the issue of trustworthiness and credibility.

The interview produced rich textual data which was transcribed by the student researcher for analysis. The textual data were analysed following guidelines set by Lincoln and Guba (1985). As a result of the iterative process, data were organized into similar categories from which themes were developed.

\section{Findings}

Analysis of the data suggests that the participants have remarkably consistent views of their purchase of dog related products and services. The main themes uncovered during the analysis include loving my pet dog means loving myself, sense of possession, attachment and sacrifice and my pet is like me. A selected sample of the participants' comments that supports each theme is provided.

\section{Theme 1: Loving my pet dog means loving myself}

According to Jyrinki (2005), pets act as vehicles for narcissistic love as owners used them to express love to oneself.

Hanna mentioned the following when explaining her decision to buy expensive supplements for both her dogs:

"Then I spend a lot on vitamins and supplements, because both of these dogs are toy breeds, they need Omega 3. And since they are vegetarian, they do not eat fish and all that. So I supplement with Omega 3 to enrich their coats. My healthcare products, shampoo, I use special shampoo. Happy is a Shih Tzu, so usually Shih Tzu has bacterial infection, cause I take him for walk, with lots of strays in the park. There are other pet owners that are not very careful with their dogs, they don't really groom them well, so they have ticks, mites etc, so I use a special, expensive designer shampoo recommended by vet; to prevent fungus and bacterial infection. Supplements recommended by vet, but I do research, I usually go for dog ranking websites, I see according to their websites, what they rank. I go to forums, dog forums... So I spend on pet food, kibble, fresh food, I spend on healthcare and supplements. So, a big chunk."

Hanna was willing to spend on both her dogs, from pet food to their supplements. She was concern over their well-being and health. Hanna showered her dogs with love and provides the best for them. Her actions could be seen as pampering and loving herself too as she further mentioned these:

"The kibble is so huge. This kind, toy dogs cannot chew. I have to soften the food for them."

"I used to spend a lot on treat. Then I found out that it's very bad because they have colouring. I used to feed them maybe two packets a month, now I only feed two packets for three months. So I give very little, very few, just to motivate them."

"So every day, every night before they sleep we clean their eyes with saline solutions, and we clean their legs with vinegar mix with water, to prevent any infection when they go for walks."

In Anne's case, she changed the veterinarian for both her Schnauzers after the previous veterinarian misdiagnosed her dog.

"I told my brother since he kind of misdiagnose my dog once, I'm kind of afraid already. So I am just going to pay a bit more and go for the hospital, just for the checkups."

Anne feared that her pet will be misdiagnosed if they went back to the previous veterinarian. She was willing to sacrifice and provide her dogs with more expensive health treatment as an alternative. Her care and concern was evidenced from her comments as follows:

“...we have to be responsible for them when you have a pet, have to pay for his expenses and everything. Even if I didn't have enough money to pay his medical; I have to find a way to."

Pets being a vehicle to express love to oneself was visible in the case of May as she expressed the following:

"Because for my poodle, she has skin problem, so last time we used to feed her with those dry dog food, those most common dog food. But she can't take it, so now we actually cooked rice with chicken and carrots, sometimes pumpkin, home-cooked food for her. Last time when buying dry dog food I will make the decision, I will do research online before getting it. I asked around. Anything for her." 
Before realizing that her dog had skin problem, May fed her dog with the usual dry dog food. Now she prepares home-cooked food, which takes more effort, as her dog could not accept oily food. Her dog's food had to be cooked separately. May emphasized her love towards her pet by stating that she will do anything for her dog. Her love for her dog showed how she expresses love to herself, as her dog is viewed as her extended self.

Ken provided both dog food and home-cooked food to his dog as he mentioned:

"We begin with the biscuits and the wet food. But we started seeing issues with his droppings, it was rather soft. So, we re-evaluate whether we want to give him dog food only. So we started giving him home-cooked food, which was chicken. Basically anything that is without any seasoning, no salt, no sugar, no pepper, sugar, just something plain, we would steam anything. We consulted the vet and the vet did give us the green light to go forth and we just started him with steamed food. Cause if not he will continue to purge, and we want him to be healthy, so we give him human food."

Ken was concerned about whether his dog should continue taking wet dog food that may not be suitable. He took the effort to re-evaluate his purchase decision in dog food. Before making any decision, he consulted the veterinarian. This shows his concern and love for his pet dog, Leo.

On the other hand, Pam was cautious when she made purchase decision on her dog's food as she explained:

“...her main food is actually dog biscuits, Eukanuba, lamb rice and that one cost me RM172 per purchase....it's very expensive. Only this does not cause skin allergy. She has skin problem, because lamb normally won't cause skin allergy...I tried a few brands in fact. This is recommended by the vet."

Pam does not mind paying for premium dog food as her dog has skin allergy. Her attention towards her dog's well-being is in a way showcasing her love for herself.

\section{Theme 2: Sense of possession}

Jyrinki (2005) pointed out that control over and by possessions, in this case, pets is a significant element when an object is viewed as extended self. This theme is derived from the sub-theme, control.

May mentioned:

“Accessories like clothes? When I first bought them, yes, we bought a lot, but now, because my dogs don't really like to wear them. Nice dresses, I chose myself. ... I will force her to wear. Because to go out, I always bring her out. So, she needs a lot of nice dresses. But now she seldom goes out. When she sees the clothes, she will just hide. But I will just make her wear. Last time when we bring her to Genting Highlands, those cold places, so she needs to wear a hoodie."

May is of the view that her dog needs to be dress-up when going out of the house. She felt just like humans, putting on beautiful clothes when leaving the house or meeting friends or family is important. It was necessary in her opinion that her dog wears a hoodie when they travel to a cooler environment. May is actually portraying her own need for extra clothing in cooler places onto her dog. She ignored the fact that her dog has a natural coat of fur that is able to protect it from the elements. May also did not consider that her dog may be uncomfortable putting on those clothes. Her actions show that she has a strong sense of control over her dog.

Pam also showed a sense of possession over her dog, Ruby.

“...I'm very strict, especially the small dog. I caned her before, because she doesn't listen, she wants to run away from the house, wants to play outside...So, I caned her a few times."

As her dog is kept indoors, Pam spayed Ruby as she wants to maintain cleanliness in her house. This indicates she wants to have control over her dog. She explained:

"I spay her when she was seven months old, because she was very messy, running about. Everywhere is messy, so dirty."

Ken mentioned how important it is to have some degree of control over his pet:

“...we did send him for training, but before that, to walk him in the park is very difficult, because he would tugged and pull quite often."

According to Ken, the leash that he chose for his dog is also to exert more control. He said the following:

“....after that we didn't use that (harness that could be stretch longer), that second product, just stick to the normal string leash. Because, we...my dad, I don't know, he didn't like the one that can pull longer, cause if you are walking, walking the dog along the road and the fact that the dog has a feeling to pull more and 
he might just run, from the side to the middle of the road and it's very dangerous. So more control was required, so he preferred just the normal leash, that can ...easier to control."

Hanna, exercised control over her dogs as she described the following:

“...they love the food I love...I'm vegetarian, so they love potatoes, they love carrots, they love carrots, they love lettuces, they love cauliflower, broccoli...they enjoy whatever I have."

Hanna controlled both her dogs' diet, as she is a vegetarian. She assumed that both her dogs have similar dietary requirements like herself.

\section{Theme 3: Attachment and sacrifice}

The type of attachment towards an object could reflect whether certain object is just mnemonic value or it reflects pet owner's extended self (Jyrinki, 2005). To view object as an extended self is where consumers are functionally and emotionally attached to towards it (Jyrinki, 2005).

When talking about her Shih Tzu and Chihuahua, Hanna emphasized these:

"They are not really my pets, they are my fur kids. They are part of family. My babies."

She voiced her strong attachment towards both her dogs as follows:

"I will never, I never... I don't think I can be separated from my Chihuahua. Happy (her other dog) also. I think they will die if they stay anywhere, even for one hour. I send them for grooming; the groomer told me they got separation anxiety. That means they miss me so much, that they miss me and my maid so much."

Hanna explained that her dogs will get upset and traumatized at the groomer. She ensures that her dogs go through minimal stress as follows:

“...I send to the groomer, the groomer is very good, they got this understanding. I will come back in one and a half hour to two hours, so she will do my dog then and there, as is when is. If she says we have to wait for 3, 4 hours, I won't send my dog. So, as soon as she is ready, I'll walk across. She says "okay, okay, you can send your pet now." So my dog doesn't have to be traumatised so long."

As she is strongly attached to her dogs, Hanna emphasized that she will never send them for boarding. She explained how she felt as follows:

"I will never send them for boarding. They cannot leave the house, this is their home. Definitely I feel anxious when away from my dogs. When I'm caught up in work, I forget. It's at night that I miss them the most, because I sleep with them, then I miss my dogs."

Hanna strongly views that her house is home for her dogs. She could not bear the idea of her dogs being kept in cages at pet hotels. She never uses such services even though she needs to be away.

As she treats them like her own children, she would call home when she is away just to hear their 'voices'. She explained:

"I call back, my maid will put the phone against their ear, I will talk to them, they will talk back....So I do miss my pets."

May, who obtained her dog as her birthday present described how attached she is towards her poodle:

"During high school time, when I have more free time, I bring them (she has two pets, but favor more on her Poodle) out more, I bring them to many places, brought them to Cameron, to Ipoh, to my dad's hometown, I bring them around. They will travel with is whenever we go for outstation. We can't leave them alone. Unless we travel to overseas, then we have no choice but to leave them behind. But my grandparents will be at home to take care of them. My pets are never left alone."

May did not use the hotel services for pets as she will bring her pets along whenever she travels. If she can't bring them with her, she leaves them in the care of her grandparents. This is to ensure they are in the hands of people she trusts.

On the other hand, Anne checks-in her dog at a pet hotel when she is away. She makes it a point to keep in contact with the hotel either through their website or by calling the hotel to enquire on her dogs. She mentioned the following:

"Of course I miss my dogs when I'm away, that time I went Penang...earlier years before I get him (Dusty), I'll check, because Puppy Cottage right, they got CCTV. So sometimes I will just log in to look, but I don't know which one is my dog. So many dogs. If not I just call them up. Even overseas I call, call the Cottage 
and ask. Call the people in-charge, the employee. Maybe every day, but depends where am I. If I am overseas, two days once. About two, three days of holiday I will call one, just to check."

Anne is attached to her dogs to the extent that she fears for their safety. She explained this:

"Nah, honestly, I think the uglier they are the better. Because when I shave my dogs right, they look like mouse, they don't look like their breed. So I told...my dad will come back and say ugly, ugly, because I think he a bit "love face", but nobody comes and see the dog. But it's just that he thinks it's ugly because they don't look same breed. But I say I don't care, it's hot, they are not going for show and you want so pretty for what? Later people want to take from me." Yea, I don't want that to happen (stolen dogs)."

She prefers her dogs to be ugly then to be stolen. She also mentioned:

"I, actually right now, even if I go out shopping with friends or go out dinner right, I'm just worried that my dogs gonna get stolen."

It is obvious that Anne is very emotionally attached to both dogs. Regardless whether she on a trip or just going out with friends, she always thinks about her dogs safety. This shows the potential market for dog's insurance or security.

Anne's strong attachment towards her dogs is evidenced as she is willing to sacrifice and find ways to give her pets a better health treatment and higher quality pet food. She mentioned:

"So now he is okay already. His pimple thing all gone, his stones are settled, then after now these few years, he is eating under vet's recommendation for food, imported one. What to do, we have to be responsible for them when you have a pet, have to pay for his expenses and everything. Even I didn't have the money to pay his medical; I have to find a way to."

Pam chose a pet hotel which is in close proximity to her house, even though she is aware of its poor hygiene. She had no other alternative as her dog is afraid to travel long distance in the car. She mentioned:

"...the hotel condition is actually not so good, even though that place, that one nearby my house, the vet and all that, they have all these hotels. The whole place is not very hygienic, they didn't keep, maintain the place well, so actually is not good."

“...my dog, she doesn't want to travel in the car so much...she's not so excited, like so traumatic. So, I do not want to put her into that kind of situation."

\section{Theme 4: My pet is like me}

Jyrinki (2005) stated that pets' reflects their owner's personalities and traits, both positive and negative. Pets are owners' definition of self. Pets are the reflection of their owners' personalities and lifestyle, which is evidenced in these pet owners. This theme was derived from the subthemes part of me and part of family.

Hanna, who claimed that her dogs are extension of her personality, mentioned these:

"The recent state of crime, I'm quite insecure." The small one, she is very insecure, but she is very protective."

"They act like human beings, they love the food that I love. Actually they don't like pet kibble so much, but now I'm putting them back on pet kibble because they cannot eat so much of human food. They need meat for protein. I'm a vegetarian. So they love potatoes, they love carrots, they love lettuces, they love cauliflower, broccoli."

She assumes that her dogs enjoy the same food that she consumes. As Hanna is also health conscious, she felt that her dogs must obtain the necessary protein from the dog food.

Pam however did not buy any clothing for her dog. She narrated:

"They are still pets; they are not human being, so I won't buy them clothes, crazy. If you go to Taiwan, especially Christmas, they also wear Christmas, the Santa Claus clothes. No, when these people buy something, they feel happy about it, when they put on the dog, they feel happy about it, but the dog they don't like it, I'm sure all dogs don't like these kind of stuff. They don't need, they still wear, wear socks when they walk on the streets, they wear socks. Oh my goodness, I said this is actually... in fact is a torture to be a pet of these people."

For Pam, she opines that it is not practical to dress up her pets. She feels it is just to satisfy the pet owners need. Pam did not purchase any accessories for her dog. She only purchases dog food, shampoo and uses the services of a veterinarian. 
Anne shared the following regarding purchasing fancy and expensive items for her dogs:

"I kind of disagree in buying too fancy stuff for your dogs. Clothes are okay, but like branded, expensive stuff for them. You know some people they actually buy an LV bag to carry their dog. I'm not sure whether overseas they sell it, if I'm not mistaken maybe it is fake, I'm not sure. But I saw those dog carries, you know people goes shopping, they actually have LV designs on it. And you know those celebrities they bought those diamond collars for the dogs, I think is pointless. I rather buy nice food for them to eat. They don't even know that is diamond."

May commented this:

"A lot of people say the dog looks like me a lot. That she is tall and skinny and her voice is very sharp. When people say that Deedee looks a lot like me I would thought of that's how a family should be. Cause we have been looking at each other's face for every day, and she used to sleep on the same bed with me, of course we do look alike."

"I dress her up just to satisfy my own esteem."

\section{Discussion}

Generally, the participants showed evidence that these pet dogs are part of their extended selves. According to Belk (1989), self-extension should be viewed more of a relative than an absolute construct. Participants like Hanna and Pam showed a stronger self-extension on their pets as compared to the other participants. This could possibly be due to them owning their dogs over a longer period as compared to the rest. Some participants like Hanna regard her pet dogs as her furry kids. The participants mentioned that they talk to their dogs and treat them as part of the family.

The participants love for their pet dogs is evidenced as they went the extra mile to ensure their dogs' well-being and health. They spend a large sum of monies on pet food, healthcare, supplements, grooming services and other products. These participants also sacrificed their time and made the effort to consult their friends, veterinarians and participate on dog forums to provide the best for their pets. Several participants like Pam were willing to pay a premium for the dog products and services as long as it made their pets comfortable. This is in line with Jyrinki and Leipamaa-Leskinen (2006) who mentioned that pet owners want to show their attachment and control over their dogs by making sure they get the best quality. Owners like Hanna indicated her displeasure with the quality of locally produced dog food in comparison with imported brands. Hence, dog food manufacturers must emphasise more on quality as these owners are seeking quality food for their dogs' well-being.

In addition, they also stressed the need for their pets to be in a safe and clean environment when the pets are at the groomers or pet hotels. Ken for instance sent his dog to a boarding house when he goes on holiday. He contacts the boarding house daily via text messages. Pet hotels should reduce the anxiety and concern of pet owners by providing value added services such as closed circuit television that enable pet owners to view their pets via their mobile devices. They could also provide a call-in service whereby owners could also contact and enquire about their dogs.

As the participants also showed a strong sense of control over their dogs, they made purchase decisions which they felt were in the best interest of their pets. A few of the participants like May accessorized her dog with dog clothes although she sensed that her dog dislikes it. She felt that it was necessary for dogs to dress-up whenever they were outside. Pam on the other hand, spayed her dog to maintain cleanliness. In Hanna's case, her strong sense of extended self in her dogs can be seen when she assumed that both her dogs are vegetarians like herself. She fed them with her favorite vegetables. Jyrinki and Leipamaa-Leskinen (2006) emphasised that when pets are considered as extended self, the pleasure in pets enjoying their meal could also refer to pleasure for oneself. Domestic dog food manufacturers should consider producing vegetarian pet kibble to appeal to vegetarian dog owners.

Consequently, these pet dogs are important self-identity to their owners. Hanna who is a very health conscious person extends this lifestyle onto her dogs eating patterns. Owners like Pam and Anne felt strongly against accessorizing pets with clothes and branded items respectively. This is a reflection of their personalities. Marketers should take cognizant that some owners like May, dressed up their dogs to satisfy their own esteem and to feel good. The admiration the pet receives is an admiration of the owner too as espoused by Jyrinki and Leipamaa-Leskinen (2006).

The rich purchase experiences of this group of dog owners provide marketers an insight into the dog products and services market. Understanding how owners view their pet vis-à-vis themselves is crucial when marketing dog products and services. It is clear from this research that owners who view their dogs as their extended self, 
made purchase decisions as though they were purchasing and consuming these products and services for themselves. They were willing to fork out large sums of monies, made personal sacrifices and took the extra effort in ensuring their dogs' well-being.

\section{Limitation and Future Research}

The findings from this research are limited in its ability to be generalized as only qualitative data was collected. Nonetheless, the rich understanding of the lived experiences of the participants with their pet dogs will further extend our knowledge on the purchase behavior of pet related products and services. Furthermore, the themes derived from this study can be further tested in a quantitative research.

This study was conducted specifically among dog owners in the capital city. More purchase insights could perhaps be obtained from pet dog owners in other parts of the country. The views of the disabled who rear dogs to aid them in their daily activities and owners who owned dogs to guard their properties will add more depth in this phenomenon.

In order to reduce memory errors as the participants recalled their experience with their pet dogs, a longitudinal study could be undertaken. This will enable researches to understand the purchase behavior of the dog owners at various stages of their pets' life and also the owner's. It will be interesting to understand the purchase behavior of young dog owners till they reach adulthood.

Researchers in the future could also study the purchase behavior for products and services on pets like cats, fishes, birds or even exotic pets such as snakes and iguanas. A comparative study could also be conducted to analyse the differences and similarities in the purchase behavior on pet dogs and cats, for example. Future studies could also probe whether the self-extension construct is applicable on the other types of pets.

\section{Conclusion}

With growing affluence among Malaysians and the humanisation of pet dogs, marketers must pay close attention to this growing dog products and services market. Recent years have seen the growth of pet cafes, pet spas and many other pet related services in Malaysia. The findings of this study have provided rich subjective meanings of consumers' lived experiences with their pet dogs. The contribution of the qualitative findings from this study complements the existing quantitative researches on dog owners' purchase behaviour.

This research has contributed further to the existing literature on purchase behavior of dog products and service from an Asian perspective. It also addressed a group of dog owners who considers their pet dogs as their extended self. Consequently, the understanding of this phenomenon will enable marketers to be more aware of the needs of these dog owners. Dog product manufacturers and service providers together with their marketers need to partner with dog owners to better understand their needs and wants. Dog owners are the voice of their pet dogs. Understanding why dog owners own a dog and how they live with their dogs are crucial in order for producers and marketers to develop a meaningful and profitable relationship with these dog owners.

\section{References}

Belk, R. W. (1988). Possessions and the extended self. Journal of Consumer Research, 15(2), 139-168.

Belk, R. W. (1989). Extended self and extending paradigmatic perspective. Journal of Consumer Research, 16(June), 129-132.

Belk, R. W. (1996). Metaphoric relationship with pets. Society \& Animals: Journal of Human-Animal Studies, 4, 121-145.

Belk, R. W. (2013). Extended self in a digital world. Journal of Consumer Research, 40. http://dx.doi.org/10.1086/671052

Boya, U. O., Dotson, M. J., \& Hyatt, E. M. (2012). Dimensions of the dog-human relationship: A segmentation approach. Journal of Targeting, Measurement and Analysis for Marketing, 20(2), 133-143.

Chen, A., Hung, K., \& Peng, N. (2012). A cluster analysis examination of pet owners' consumption values and behavior - segmenting owners strategically. Journal of Targeting, Measurement and Analysis for Marketing, 20(2), 117-213. http://dx.doi.org/10.1057/jt.2012.10

Euromonitor International. (2011). Southeast Asian Pet Care: Increasing Affluence Drives growth in low volume, high value markets.

Euromonitor International. (2013). Consumer lifestyles in Malaysia.

Fournier, S. (1998). Consumers and their brands: Developing relationship theory in consumer research. Journal 
of Consumer Research, 24(4), 343-373. http://dx.doi.org/10.1086/209515

Hill, R. P., Gaines, J., \& Wilson, R. M. (2007). Consumer behavior, extended-self, and sacred consumption: an alternative perspective from our animal companions. Journal of Business Research, 61, 553-562

Jyrinki, H. (2005). Pets as social self extensions - a comparative analysis among subcultures of dog owners. Kuluttajatutkimus.Nyt, 1, 69-78.

Jyrinki, H., \& Leipamaa-Leskinen, H. (2006). Pets as extended self in the context of pet food consumption. European Advances in Consumer Research, 7, 543-549.

Kiesler, T., \& Kiesler, S. (2004). My pet rock and me: An experimental exploration of the self extension concept. Human Computer Interaction Institute. Paper 85. Retrieved from http://repository.cmu.edu/hcii/85

Lincoln, Y. S., \& Guba, E. G. (1985). Naturalistic Inquiry. Sage Publications, Newbury Park, CA.

Thompson, C. J., \& Haytko, D. L. (1997). Speaking of Fashion: Consumers' Uses of Fashion Discourses and the Appropriation of Countervailing Cultural Meanings. The Journal of Consumer Research, 24(1), 15-42. http://dx.doi.org/10.1086/209491

\section{Copyrights}

Copyright for this article is retained by the author(s), with first publication rights granted to the journal.

This is an open-access article distributed under the terms and conditions of the Creative Commons Attribution license (http://creativecommons.org/licenses/by/3.0/). 